Ethiopian Journal of Environmental Studies \& Management 9(4): 523 - 533, 2016.

ISSN:1998-0507

doi: http://dx.doi.org/10.4314/ejesm.v9i4.11

Submitted: April 29, 2016

Accepted: August 03, 2016

\title{
LEACHATE CHARACTERIZATION AND ASSESSMENT OF SURFACE AND GROUNDWATER WATER QUALITIES NEAR MUNICIPAL SOLID WASTE DUMP SITE AT OKUVO, DELTA STATE, NIGERIA
}

\author{
*ASIBOR, G., EDJERE, O. AND EBIGHE, D. \\ ${ }^{1}$ Department of Environmental Management and Toxicology, College of Science, Federal \\ University of Petroleum Resources, P.M.B. 1221, Effurun, Delta State, Nigeria
}

\begin{abstract}
The paucity of standard engineered landfills in Nigeria has given rise to the proliferation of open waste dumpsites. The environment can be impacted negatively by leachates from these dumpsites if not properly managed. This study aimed at assessing the characteristics of municipal solid waste leachate and its contamination potential on surface and groundwater. Leachate, groundwater and surface water samples were collected from refuse dump site, saver pit, borehole and river in the vicinity of the Okuvo refuse dump site. Physical parameters, oxygen demanding parameters, nutrients and heavy metals were investigated using standard laboratory procedures. Results obtained were compared with standards from national regulatory agencies. The BOD/COD ratio for the leachates varied from 0.34 to 0.52, indicating high organic content. Surrounding water bodies show low pollution from the discharged leachates as indicated by unobjectionable odour and colour, $\mathrm{pH}$ (6.55-7.20), DO (3.02-6.60 $\left.\mathrm{mgl}^{-1}\right), B O D\left(0.55-2.90 \mathrm{mgl}^{-1}\right), C O D\left(1.98-7.45 \mathrm{mgl}^{-1}\right)$, phosphate $\left(0.18-0.52 \mathrm{mgl}^{-1}\right)$ and nitrate $\left(0.06-0.24 \mathrm{mgl}^{-1}\right)$ results. Heavy metals concentrations range from $0.011-0.028 \mathrm{mgl}^{-1}, 0.005-0.018 \mathrm{mgl}^{-1}, 0.032-0.096 \mathrm{mgl}^{-1}, 0.001-0.008 \mathrm{mgl}^{-1}, 0.001-$ $0.003 \mathrm{mgl}^{-1}$ and $0.010-0.018 \mathrm{mgl}^{-1}$ for $\mathrm{Ni}, \mathrm{Cr}, \mathrm{Fe}, \mathrm{Pb}, \mathrm{Cd}$ and $\mathrm{Mn}$. Concentrations values for Arsenic and mercury were $<0.001 \mathrm{mgl}^{-1}$. These were all within the country's regulatory limits except few recorded concentrations of nickel where concentrations were observed to be slightly higher. These observed results may be as a result of the young age of the dumpsite. Some proactive remedial actions were suggested to curtail future environmental and health implications posed by the dumpsite. The study concludes that in spite of absence of pollution, the groundwater beneath the landfill has the tendency of being polluted in the distant future except the refuse dump site is upgraded to an engineered standard landfill with effective monitoring protocols put in place.
\end{abstract}

Key Words: Landfills, solid waste, contamination, surface and water pollution

\section{Introduction}

Solid waste management is a serious problem in Nigeria, as most cities lack standard engineered landfills. Open landfills are the primary means of municipal solid waste (MSW) disposal in many countries worldwide including
Nigeria because they offer low economic costs and have capacity to accumulate large amounts of solid waste compared to other methods such as incineration (Mohajeri et al., 2010; Tsarpali, 2012).

Leachate formation occurs when the percolating water dissolves the soluble

*Corresponding Author: Asibor, G.

Email: asibor.godwin@fupre.edu.ng 
components out of the solid material. This is generally heavily contaminated and consists of complex waste water that is very difficult to deal with (Daud et al., 2009; Foul et al., 2009; Mohajeri et al., 2010). Further contaminants are added depending on the type of solid waste and biodegradation stage.

Many factors influence the leachate composition including the types of wastes deposited in the landfill, composition of wastes, moisture content, the particle size, the degree of compaction, the hydrology of the site, the climate, and age of the fill and other site specific conditions such as landfill design and type of liner used if any (Rafizul et al., 2011). As a result, surface water, groundwater reservoirs and soil layers become vulnerable to pollution from the dumpsite.

A number of incidences have been reported in the past where leachates have been implicated in the contamination of surrounding soil and groundwater aquifer or nearby surface water, while several studies (Longe and Enekwechim, 2007; Longe and Balogun, 2010; OhwoghereAsuma and Aweto, 2013) have shown that leachates outflow and percolation are source of ground and surface water pollution adjacent to landfill sites. It is therefore expedient that a comprehensive study be carried out on the assessment of pollution levels from these dumpsites, taking into account related parameters.

Majority of the people in the developing countries depends on shallow groundwater wells and boreholes for their portable water need as a result of poor public water supply infrastructures. Provisions of groundwater are often carried out by non-professionals and the potential of groundwater contamination by refuse dump sites, septic tanks are often not taken into consideration when water wells drilled. The consumption of groundwater from contaminated aquifers goes with health hazard implication.

Recently MSW operators in the major cities in Delta State of Nigeria were directed by state government to relocate all the designated operated open landfills outside the cities, to places far from known surface water bodies. Okuvo Village has found itself in this state being a town few kilometres away from the twin city of Warri-Effurun. WarriEffurun is in the heart of the hydrocarbon industry in the western Niger Delta of Nigeria. With a population of about eight hundred thousand people (NBS, 2009), majority of the people in this city depends on shallow groundwater wells and boreholes for their portable water need, which is promoted by lack of public water supply infrastructures. The aim of this paper is to characterize leachates from the Okuvo municipal open solid waste dump site and delineate the impact of it on both groundwater and surface water qualities in the vicinity of the dump site.

\section{Materials and Methods Site Description}

The Okuvo Open Dump Site is located along Sapele-Benin Express Road, Okuvo Village, in Okpe Local Government Area of Delta state, Nigeria. It is about 2 kilometers away from the Warri Metropolis; a densely populated metropolis comprising Warri, Uvwie, Udu and Okpe Local Governments Areas with a population of about 800,000 (NBS, 2009) and the heart of the western operations of petroleum industry in Nigeria. The dump site is located in an 
expanse land measuring about 12 acres while the dumpsite for now occupied about 2 acres of the dumpsite area. Operations at the dumpsite commenced in late 2011 and it receives an estimated quantity of about 45 tons of municipal solid wastes daily (personal contact). The wastes are largely from domestic and commercial sources from Warri, Effurun, Ekpan, Ugborikoko, Uvwian, Jeddo, Ubeji, Okuokoko, Agbarho and some other adjourning towns. Additional wastes from poultry farms and slaughterhouses within the aforementioned cities and towns also parts of the waste. Wastes are transported to the place by PSP (Private Sector Partnership) collection trucks from different parts of the city and dumped haphazardly without prior segregation. The site is characterized by landfill fires mostly due to spontaneous combustion which are more prevalent during the dry season. There is a saver pit within the area which is about $200 \mathrm{~m}$ from the waste dumpsite, while the borehole water close to this site is used for the washing of the garbage collection vehicles and maintenance of heavy earth moving equipment.

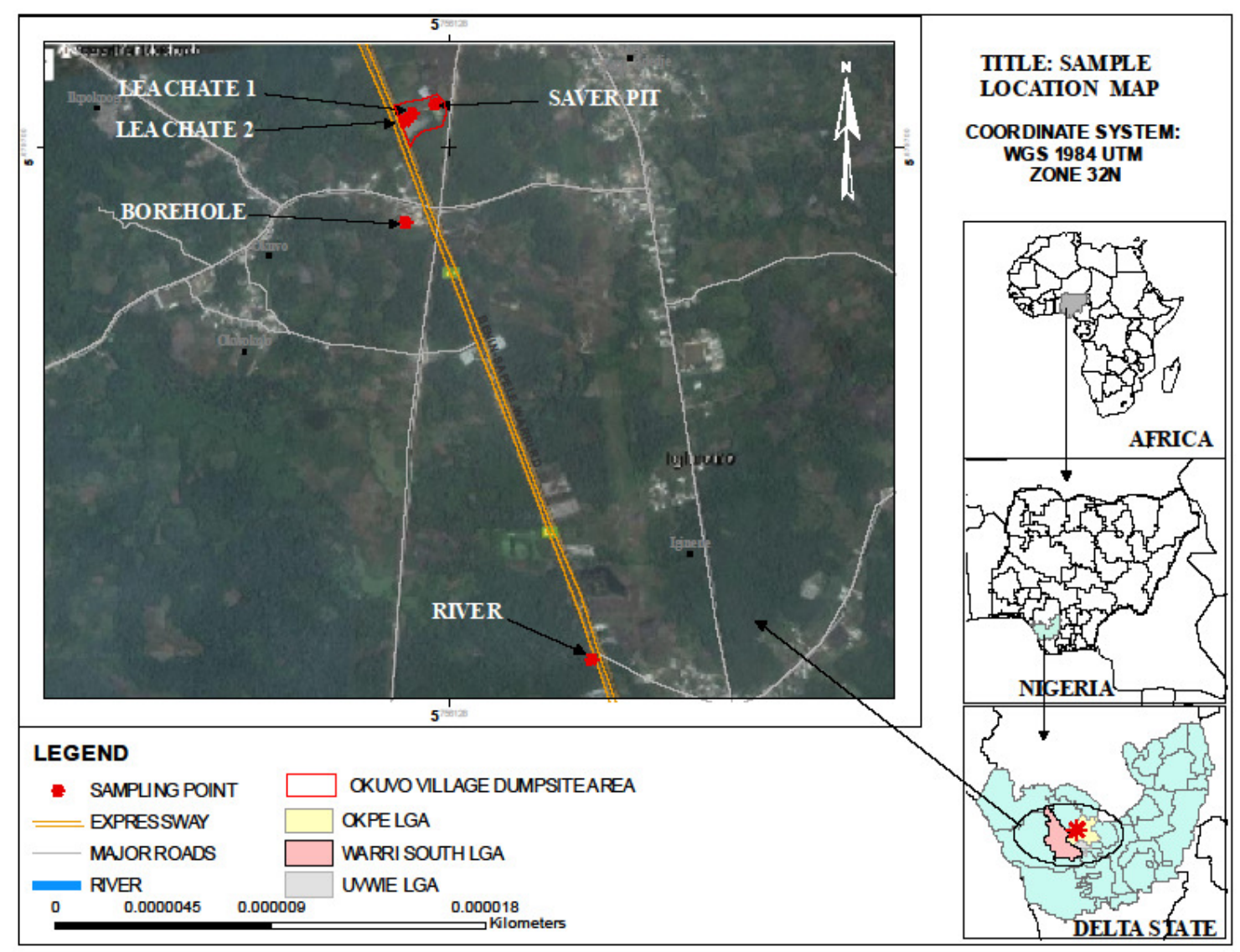

Figure 1: Map of Okuvo Waste Dumpsite and Sampling Sites 


\section{Sampling}

Leachates samples were collected from two trenches dug around the dumpsite at 50meters distance from each other. Water sample was collected from a saver pit which is about 75 meters from the dump site, while Borehole and river water sample were also collected outside the dumpsite area in the village. Samples location coordinates were identified with the aid of GPS (Table 1).

Samples containers were washed with detergent and rinsed with de-ionized water, thereafter rinsed with samples fluids prior to collection. Rinsing with sample waters was a precautionary measure taken to avoid any interference that may arose from using contaminated samples containers. To preserve samples for heavy metals, COD, nitrates and ammonia analysis, few drop of concentrated hydrochloric acid was added to separate samples containers. Water samples were preserved in a cool box and subsequently taken to the laboratory for chemical analysis.

Table 1: Sample Location and Coordinates

\begin{tabular}{llll}
\hline S/N & Sample Description & Coordinates & \\
\cline { 3 - 4 } & & Northing & Esating \\
\hline 1 & Leachate A & N05 76' 40.7" & E005 75' 45.36" \\
2 & Leachate B & N05 76'41.8" & E005 75' 45.38" \\
3 & Borehole & N05 89' 55.9" & E005 86' 56.7" \\
4 & Saver Pit & N05 75' 40.9" & E005 76' 45.37" \\
5 & River & N05 75'44.8" & E005 70'43.38" \\
\hline
\end{tabular}

\section{Laboratory Analysis}

The chemical analysis was initiated immediately as soon as the samples arrived at the laboratory in accordance with standard methods (APHA, 2005). The various physico-chemical parameters analyzed for all the samples include $\mathrm{pH}$, temperature, total dissolved solids (TDS), electrical conductivity, sulphates, nitrates, phosphates, dissolved oxygen (DO), biological oxygen demand (BOD) and chemical oxygen demand (COD). Heavy metals analyzed include iron, lead, chromium, nickel, cadmium, arsenic and manganese.

\section{Results and Discussion}

The characteristics of the leachates the dumpsite, surface and groundwater samples presented in Tables 2 and 3. The odours from the leachates are objectionable while the colour were observed to be rustic black and oily. The temperature of the leachates varied from $29.8{ }^{\circ} \mathrm{C}$ to $32.4{ }^{\circ} \mathrm{C}$. These values are consistent with temperature from typical tropical regions.

The mean $\mathrm{pH}$ values for the two leachate samples are $5.78 \pm 0.54$ and $5.54 \pm 0.64$. The low value of $\mathrm{pH}$ is a strong reflection of an acid producing phase during the decomposition of wastes, the low value of $\mathrm{pH}$ measured, according to Alloway (1995) is an indication of leachate undergoing anaerobic or methanogenic phase. Fatta et al. (1998) observed that the initial period of leachate formation is characterized by very low $\mathrm{pH}$ values. 
Table 2: Physicochemical characteristics of leachates and water samples

\begin{tabular}{|c|c|c|c|c|c|c|}
\hline $\mathrm{S} / \mathrm{N}$ & Parameter & $\begin{array}{l}\text { Leachate } \\
\text { (LC1) }\end{array}$ & $\begin{array}{l}\text { Leachate } \\
\text { (LC2) }\end{array}$ & Borehole & Saver Pit & River \\
\hline 1 & Odour & Objectionable & Objectionable & Non & Non & Non \\
\hline 2 & Colour & Grey Black & Grey Black & Colorless & Colorless & Colorless \\
\hline 3 & $\mathrm{pH}$ & $5.78 \pm 0.54$ & $5.54 \pm 0.64$ & $6.80 \pm 0.88$ & $6.46 \pm 0.12$ & $6.93 \pm 0.48$ \\
\hline 4 & Temperature $\left({ }^{\circ} \mathrm{C}\right)$ & $31.3 \pm 2.28$ & $30.4 \pm 1.86$ & $29.6 \pm 1.33$ & $30.2 \pm 2.32$ & $27.1 \pm 3.87$ \\
\hline 5 & TDS (mg/l) & $2,330 \pm 40.4$ & $2,120 \pm 20.8$ & $15.2 \pm 3.2$ & $20.1 \pm 2.1$ & $26.3 \pm 4.3$ \\
\hline 6 & Conductivity $(\mu \mathrm{s} / \mathrm{cm})$ & $4,194 \pm 68.6$ & $3,556 \pm 54.8$ & $87.36 \pm 2.3$ & $66.18 \pm 4.2$ & $150.9 \pm 9.8$ \\
\hline 7 & $\mathrm{DO}(\mathrm{mg} / \mathrm{l})$ & - & - & $3.20 \pm . .88$ & $4.30 \pm 1.02$ & $5.90 \pm 0.98$ \\
\hline 8 & BOD (mg/l) & $41.2 \pm 6.4$ & $35.8 \pm 8.4$ & $1.00 \pm 0.02$ & $1.40 \pm 0.04$ & $2.10 \pm 0.12$ \\
\hline 9 & $\mathrm{COD}(\mathrm{mg} / \mathrm{l})$ & $103.11 \pm 11.6$ & $98.25 \pm 12.2$ & $2.26 \pm 0.88$ & $4.22 \pm 1.02$ & $5.25 \pm 1.22$ \\
\hline 10 & BOD5/COD & $0.398 \pm 0.03$ & $0.400 \pm 0.05$ & $0.442 \pm 0.05$ & $0.332 \pm 0.06$ & $0.400 \pm 0.02$ \\
\hline 11 & Nitrate $(\mathrm{mg} / \mathrm{l})$ & $38.11 \pm 6.2$ & $29.08 \pm 4.8$ & $0.13 \pm 0.01$ & $0.25 \pm 0.00$ & $0.19 \pm 0.00$ \\
\hline 12 & Ammonia (mgl) & $4.08 \pm 2.92$ & $3.92 \pm 1.88$ & $0.09 \pm 0.01$ & $0.12 \pm 0.14$ & $0.14 \pm 0.08$ \\
\hline 13 & Phosphate (mg/l) & $63.26 \pm 6.4$ & $57.33 \pm 4.4$ & $0.37 \pm 0.04$ & $0.74 \pm 0.04$ & $0.43 \pm 0.02$ \\
\hline 14 & Sulphate $(\mathrm{mg} / \mathrm{l})$ & $110.4 \pm 16.8$ & $104.5 \pm 12.8$ & $1.21 \pm 0.02$ & $1.82 \pm 0.02$ & $1.38 \pm 0.08$ \\
\hline 15 & Nickel (mg/l) & $0.215 \pm 0.08$ & $0.287 \pm 0.04$ & $0.014 \pm 0.012$ & $0.036 \pm 0.02$ & $0.021 \pm 0.00$ \\
\hline 16 & Chromium (mg/l) & $3.873 \pm 1.02$ & $2.964 \pm 0.88$ & $0.009 \pm 0.012$ & $0.017 \pm 0.002$ & $0.012 \pm 0.004$ \\
\hline 17 & Iron $(\mathrm{mg} / \mathrm{l})$ & $10.217 \pm 4.2$ & $12.773 \pm 3.6$ & $0.046 \pm 0.001$ & $0.095 \pm 0.004$ & $0.060 \pm 0.002$ \\
\hline 18 & Lead $(\mathrm{mg} / \mathrm{l})$ & $0.843 \pm 0.11$ & $0.942 \pm 0.18$ & $0.003 \pm 0.002$ & $0.011 \pm 0.012$ & $0.006 \pm 0.002$ \\
\hline 19 & Cadmium (mg/l) & $0.504 \pm 0.04$ & $0.731 \pm 0.06$ & $0.001 \pm 0.001$ & $0.005 \pm 0.002$ & $0.002 \pm 0.004$ \\
\hline 20 & Manganese (mg/l) & $0.144 \pm 0.06$ & $0.228 \pm 0.04$ & $0.013 \pm 0.002$ & $0.030 \pm 0.001$ & $0.016 \pm 0.001$ \\
\hline 21 & Arsenic (mg/l) & $0.043 \pm 0.02$ & $0.031 \pm 0.02$ & $<0.001 \pm 0.001$ & $0.006 \pm 0.001$ & $<0.001 \pm 0.001$ \\
\hline 22 & Mercury (mg/l) & $<0.001 \pm 0.00$ & $<0.001 \pm 0.00$ & $<0.001 \pm 0.00$ & $<0.001 \pm 0.00$ & $<0.001 \pm 0.00$ \\
\hline
\end{tabular}

Dissolved oxygen was not detected in the leachates as the whole dissolved oxygen has been used up by the constituents. If the leachates found its way to the surface and groundwater, it may exert significant influence on the available oxygen and deplete it. This in turn may affect the existence of life in waterbodies close to the leachates site. The value of BOD ranged from 32.6-68.8 $\mathrm{mg} / \mathrm{l}$ with mean values of $41.2 \pm 6.4 \mathrm{mg} / \mathrm{l}$ and $35.8 \pm 8.4 \mathrm{mg} / \mathrm{l}$ for leachates 1 and 2 respectively. The low values of BOD may be as result of dilution caused by heavy rains during the period samples were collected. COD values ranged from $89.4 \mathrm{mg} / \mathrm{l}$ to $168.5 \mathrm{mg} / \mathrm{l}$. The values are relatively different for all leachate samples. The low values obtained for both BOD and COD are normal range for typical municipal landfill leachates
(Ehrig, 1989; Christensen et al., 2001; Ojoawo et al., 2012; Agbozu et al., 2015) due to microbial activity in the leachate decomposition and dilution from rainfall during this period of the year. The calculated ratio of $0.3-0.5$ for BOD5/COD suggests moderate organic strength for leachates (Yoshida et al., 2002). The BOD/COD is also used to portray the lifespan of the landfill. $\mathrm{BOD} / \mathrm{COD}$ varying from $0.4 \mathrm{mg} / \mathrm{l}$ to $0.6 \mathrm{mg} / \mathrm{l}$ is a characteristic of a young landfill and this ratio decreases to $0.05 \mathrm{mg} / \mathrm{l}$ to $0.2 \mathrm{mg} / \mathrm{l}$ for a matured landfill.

The concentration of nitrate in the leachate ranged from $23.3 \mathrm{mg} / 1$ to $62.1 \mathrm{mg} / \mathrm{l}$. According to Fatta et al. (1999) nitrates are conservative contaminants as they are not affected by biochemical processes and natural decontamination 
processes taking place inside the landfill as well as their infiltration into the vadose zone. Nitrates are potential threat to groundwater pollution as they sink into the vadose zone. Elevated nitrates levels which may find their way to surface and groundwater are potential source of concerns as they have been implicated in potable water contamination. Nitrate is particular health concerns in the body because it reduces the amount of oxygen that the blood can carry (methemoglobinemia) especially in children as a result of drinking water contaminated with elevated nitrates. The value of ammonia ranged between $2.68 \mathrm{mg} / \mathrm{l}$ to $10.83 \mathrm{mg} / \mathrm{l}$ for all leachate samples. The values of ammonia are low and may not be able to inhibit the activities of microorganisms that promote anaerobic processes. Other anions analyzed were sulphates and phosphates. Sulphates values for the samples of leachate examined are quite variable and may have emanated from oxidation of iron sulphide present in the dump. The maximum value obtained was $124.4 \mathrm{mg} / \mathrm{l}$ for sulphate, while the maximum concentration recorded for phosphate was $82.6 \mathrm{mg} / \mathrm{l}$. The presence of phosphates in a leachate is dangerous as its presence in water increases eutrophication and correspondingly promotes the growth of algae in waterbodies. Algal bloom may blanket surface water, used up the available dissolved oxygen and thereby prevent other aquatic organisms from accessing this life-supporting substance.

Nickel, chromium, iron, lead, cadmium, manganese, arsenic and mercury were the heavy metals content of the leachate samples analysed (Table 2). Iron has the highest concentration with a mean value of $11.98 \mathrm{mg} / \mathrm{l}$ of all the heavy metals present in the leachate. It was followed by chromium and lead; while mercury has the lowest value followed by arsenic and manganese. The high level of iron in the leachate samples is evidence of dumping of iron and steel scraps wastes in the dumpsite and the high content of iron present in shallow groundwater aquifers in the Niger delta. The quantity of lead, though small, is attributed to availability of lead-related wastes such as batteries, paints and photography processing chemicals in the dump site. The different heavy metals detected are indication that the Okuvo open dumpsite receives variety of wastes from different waste stream. This is due to the fact waste from both industrial, commercial and household items are deposited here without any form of segregation. The low value of heavy metals obtained maybe attributed to the dumping of mainly municipal wastes and small percentage of industrial wastes.

\section{Quality Characteristics of Groundwater and Surface Water}

As expected, the borehole, saver pit and river water's were without odour and colourless. These are some of the physical attributes of potable water. Temperature of the water ranged from $28.4-31.8{ }^{\circ} \mathrm{C}$ (Borehole), $29.4-32.8^{\circ} \mathrm{C}$ (Saver Pit) and $25.8-30.2^{\circ} \mathrm{C}$ (River) respectively. The low temperature of the river can be attributed to dense shades that cover most of the watercourse, while the high temperature of the Saver Pit is due to the open nature to direct effect of the sunrays. Cool water is generally more palatable than warm water, and temperature will have an impact on the acceptability of a number of other inorganic constituents and chemical contaminants that may affect taste. High 
water temperature enhances the growth of microorganisms and may increase problems related to taste, odour, colour and corrosion (WHO, 2011).

Table 3: Comparison of Mean Leachates and Water Samples Values with FEPA Standards and SON

\begin{tabular}{|c|c|c|c|c|c|c|c|}
\hline $\mathrm{S} / \mathrm{N}$ & Parameter & $\begin{array}{l}\text { Mean leachate } \\
\text { value }\end{array}$ & $\begin{array}{l}\text { Mean } \\
\text { Surface } \\
\text { value }\end{array}$ & $\begin{array}{l}\text { Mean under- } \\
\text { ground } \\
\text { water value }\end{array}$ & $\begin{array}{l}\text { FEPA } \\
\text { Standards } \\
(1991) \\
\end{array}$ & SON (2007) & $\begin{array}{l}\text { WHO } \\
(2011)\end{array}$ \\
\hline 1 & Odour & Objectionable & Non & Non & N/A & $\begin{array}{l}\text { Un- } \\
\text { objectionable }\end{array}$ & - \\
\hline 2 & Colour & Rustic-yellow & Colorless & Colorless & N/A & $15^{J}$ & - \\
\hline 3 & $\mathrm{pH}$ & 5.76 & 6.93 & 6.80 & $6.0-9.0$ & $6.5-8.5$ & - \\
\hline 4 & Temperature $\left({ }^{\circ} \mathrm{C}\right)$ & 31.05 & 27.1 & 29.6 & $35^{\circ} \mathrm{c}$ & - & - \\
\hline 5 & TDS (mg/l) & 1875 & 26.3 & 15.2 & 2,000 & - & - \\
\hline 6 & $\begin{array}{l}\text { Conductivity } \\
(\mu \mathrm{s} / \mathrm{cm})\end{array}$ & 3375 & 150.9 & 87.3 & N/A & 1000 & - \\
\hline 7 & $\mathrm{DO}(\mathrm{mg} / \mathrm{l})$ & 0 & 5.90 & 3.20 & N/A & - & - \\
\hline 8 & BOD (mg/l) & 38.25 & 2.10 & 1.00 & 30 & - & - \\
\hline 9 & COD (mg/l) & 95.68 & 5.25 & 2.26 & 75 & - & - \\
\hline 10 & BOD/COD & 0.399 & 0.40 & 0.442 & 0.40 & - & - \\
\hline 11 & Phosphate (mg/l) & 60.30 & 0.43 & 0.37 & 50.0 & - & - \\
\hline 12 & Sulphate (mg/l) & 106.98 & 1.38 & 1.21 & 100.0 & 100 & - \\
\hline 13 & Ammonia (mg/l) & 4.00 & 0.14 & 0.11 & - & - & - \\
\hline 14 & Nitrate (mg/l) & 32.59 & 0.19 & 0.13 & 20.0 & 50 & 50 \\
\hline 15 & Nickel (mg/l) & 0.20 & 0.021 & 0.014 & 0.01 & 0.02 & 0.07 \\
\hline 16 & Chromium (mg/l) & 3.32 & 0.012 & 0.009 & 0.20 & 0.05 & 0.05 \\
\hline 17 & Iron (mg/l) & 9.99 & 0.060 & 0.046 & 0.05 & 0.3 & - \\
\hline 18 & Lead (mg/l) & 0.74 & 0.006 & 0.003 & 0.05 & 0.01 & 0.01 \\
\hline 19 & Cadmium (mg/l) & 0.47 & 0.002 & 0.001 & $<1$ & 0.003 & 0.003 \\
\hline 20 & Manganese (mg/l) & 0.14 & 0.016 & 0.013 & 0.05 & 0.02 & - \\
\hline 21 & Arsenic (mg/l) & 0.04 & $<0.001$ & $<0.001$ & 0.1 & 0.01 & 0.01 \\
\hline 22 & Mercury (mg/l) & $<0.001$ & $<0.001$ & $<0.001$ & N/A & 0.001 & 0.006 \\
\hline
\end{tabular}

The $\mathrm{pH}$ value for surface and groundwater samples was slightly acidic to neutral. These values fall within the range of potable water as prescribed the Nigeria standard for drinking water quality (SON, 2007) and for most domestic uses (FEPA, 1991). The mean $\mathrm{pH}$ of the surface water and groundwater

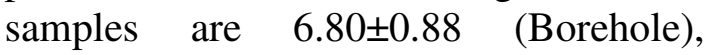
$6.46 \pm 0.12$ (Saver Pit) and 6.93 \pm 0.48 (River) as indicated in Table 2. Generally the $\mathrm{pH}$ ranged from $6.35-7.20$. These $\mathrm{pH}$ values are consistent with regulatory limits from national bodies like Federal
Environmental Protection Agency (FEPA) and Standard Organisation of Nigeria (SON). Although $\mathrm{pH}$ usually has no direct impact on consumers, it is one of the most important operational water quality parameters, which influences other water parameters (WHO, 2011). The electrical conductivity (EC) of water is reflection of the quantity of ionic constituents dissolved in it. The obtained conductivity ranges from 78 to $96 \mu \mathrm{S} / \mathrm{cm}$ for borehole water samples, while the surface water and saver pit samples varied from 135 to $172 \mu \mathrm{S} / \mathrm{cm}$ and 54 to 
$82 \mu \mathrm{S} / \mathrm{cm}$. All the surface and underground water values fall within the acceptable national regulatory limits. The low level of electrical conductivity may be attributable to the bedrock materials around the vicinity of the leachate. The bedrock material was observed made up of clay materials and this to an extent limits the percolation of leachates from the refuse dumpsite into the groundwater beneath it. A similar trend was observed in the value of total dissolved solids in the waterbodies. According to (WHO, 2011) high level of TDS may be responsible for reduction in the palatability of water, inflict gastrointestinal inconveniences in human, may cause laxative effect particularly upon transits and may be objectionable to consumers. The dumpsite leachate has minimal effects on the TDS and conductivity of both surface and underground water sources.

Recorded dissolved oxygen was slightly low for borehole $(3.20 \pm 0.88 \mathrm{mg} / \mathrm{l})$ but slightly high for river $(5.90 \pm 0.98 \mathrm{mg} / \mathrm{l}) \quad$ while oxygen demanding parameters like BOD and COD were low for both the surface and ground-waters (Table 2). The dissolved oxygen content of water is influenced by the source, raw water temperature, treatment and chemical or biological processes taking place in the distribution system. Depletion of dissolved oxygen in water supplies can encourage the microbial reduction of nitrate to nitrite and sulphate to sulphite. It can also cause an increase in the concentration of ferrous iron in solution, with subsequent discoloration at the tap when the water is aerated. However, very high levels of dissolved oxygen may exacerbate corrosion of metal pipes. COD can be utilized as a proxy for organic pollution in water. COD concentration varied from $1.88 \mathrm{mg} / \mathrm{l}$ to $7.48 \mathrm{mg} / \mathrm{l}$. Lowest COD was recorded in the borehole water, while surface water was slightly higher.

The concentration of nitrate in the waterbodies samples ranged from $0.11 \mathrm{mg} / 1$ to $0.48 \mathrm{mg} / \mathrm{l}$. These values are within the permissible level allowed for a drinking water. High concentration of nitrate is known to inhibit the distribution of oxygen within the human body (Chapman, 1992; Lee and Jones-Lee, 1993; Al-Sabahi et al., 2009). Phosphate values ranged from $0.32 \mathrm{mg} / \mathrm{l}$ to $0.98 \mathrm{mg} / \mathrm{l}$, with saver pit water having the highest value, followed by river water and borehole water having the least concentration. Although the concentration of phosphate in the waterbodies are low, it has been noted that a minute value of phosphate as low as $0.01 \mathrm{mg} / \mathrm{l}$ in groundwater promotes the growth of algal (Adekunle et al., 2007). The range of the concentration of sulphates in groundwater samples varied from $1.08 \mathrm{mg} / \mathrm{l}$ to $2.48 \mathrm{mg} / \mathrm{l}$. The obtained values are lower than the standard of 100mg/l stipulated by FEPA (1991) for portable drinking water. A similar trend was observed in the surface water samples. High concentration of sulphate in water is dangerous as it causes dehydration and diarrhea in children (Longe and Balogun, 2010).

\section{Heavy Metals in Surface and Ground Water}

Heavy metals in the surface and ground water samples were generally low. Although iron recorded the highest concentration, followed by nickel and manganese, these were very low when compared to the leachates concentrations. The very low concentrations of heavy 
metals recorded in the study area shows the roles played by the occurrence of organic soils and clayey soils underneath the municipal waste dump site in the sorption of heavy metals (OhwoghereAsuma and Aweto, 2013). Heavy metals tend to be immobile in the waste or waste- rock interface due to redox controlled reaction (Yanful et al., 1988). Also, the mobility of heavy metals is influenced by the physical sorptive mechanism and landfills posses' intrinsic in-situ ability in minimizing the mobility of toxic heavy metals (Pohland et al., 1993). These processes influencing the mobility of heavy metals in waste or soil and have the effect of attenuating the risk associated with the consumption of groundwater polluted by leachates.

\section{Conclusion}

The $\mathrm{BOD} / \mathrm{COD}$ ratios revealed that leachate from the refuse dump site vary depending on the time of the year they are collected and partially from being young to mature in age. The variation in concentration of physico-chemical parameters in the different leachates samples is basically influenced by the continuing decomposition of refuse, as result of new wastes that are being added on daily bases. The observed quality of surface water and borehole water near the refuse dump site contained more ions and cations than the groundwater samples. During wet season, decomposing refuse mixes with precipitation and subsequently flows as runoff to contaminate surface water bodies nearby. The analyzed groundwater samples obtained from the vicinity of the refuse dump site did not evidently reflect water quality that is affected by the leachates from the refuse dumpsite. This is due to distance of the refuse landfill site being very far from major waterbodies and also located away from populated areas. The distance and depth of the sink from the source of leachate has greater impact on the degree and extent of contamination of groundwater and surface water. This distance from human settlement should be maintained and land speculators should be discouraged from encroaching into this area. Finally, while it is good to keep monitoring the various dumpsites to ensure adherence to regulatory limits, it is better to upgrade the Okuvo refuse dumpsite and others into well engineered sanitary landfill by the stake holders in collaboration with relevant government agencies.

\section{References}

Adekunle, I.M., Adetunji, M.T., Gbadebo, A.M. and Banjoko, O.B. (2007). Assessment of groundwater quality in a typical rural settlement in Southwest, Nigeria. Int. $J$. Environ. Res. Public Health, 4(4): 307-318.

Agbozu, I.E., Oghama, O.E. and Odhikori, J.O. (2015). Physicochemical Characteristics and Pollution Determination ofLeachates from Warri Waste Dumpsite, Southern Nigeria. Journal of Appl. Sci. Environ. Manag., 19(3): 361-372.

Alloway, B.J. (1995). Heavy metals in soils. $2^{\text {nd }}$ edition. Chapman and Hall, London, UK.

Al-Sabahi, E., Abdulrahim, S., Zuhairi, W.Y., Al-Nozaily, F., and AlShaebi, F. (2009). The characteristics of Leachate and Groundwater Pollution at Municipal Solid Waste Landfill of Ibb City, 
Yemen. American Jour. of Environ. Sci., 5(3): 256-266.

APHA, AWWA and WEF (2005). Standard Methods for the Examination of Water and Wastewater, $21^{\text {st }}$ ed. American Public Health Association, the American Water Works Association and the Water Environment Federation Publication, Washington, DC.

Chapman, D. (1992). Water Quality Assessments. A Guide to the Use of Biota, Sediments and Water inEnvironmental Monitoring. $1^{\text {st }}$ ed., UNESCO/ WHO/UNEP, Chapman and Hall, London.

Christensen, T.H., Kjeldsen, P., Bjerg, P.L., Jensen, D.L, Christensen, J.B., Baun, A., Albrechtsen H.J. and Heron, G. (2001). Biogeochemistry of landfill leachate plumes. Appl. Geochem., 16: 659-718.

Daud, Z., Aziz, A., Adlan, M.N. and Hung, Y.T. (2009). Application of combined filtration and coagulation for semi-aerobic leachate treatment. International Journal of Environment and Waste Management, 4(3): 457-469.

Ehrig, H.J. (1989). Leachate quality: In Christensen, H.T., Stegmann, A. and Cossu, A. (ed). Sanitary landfilling: Process, Technology and Environmental Impact. London. Academic Press. Pp. 20-4

Fatta, D., Voscosa, C., Papadopouls, A. and Lizidou, M. (1998). Leachate quality of a MSW landfill. Journal of Environmental Science and Health 33(5): 749-763.

Fatta D., Papadopoulos, A. and Loizidou, M., (1999). A study on the landfill leachate and its impact on the groundwater quality of the greater area. Environ. Geochem. Health, 21(2): 175-190.

FEPA (1991). National Interim Guidelines and Standards for Industrial Effluents and Water Quality Tests. Federal Environmental Protection Agency of Nigeria.

Foul, A.A., Aziz, H.A., Isa, M.H. and Hung, Y. (2009). Primary treatment of anaerobic landfill leachate using activated carbon and limestone: Batch and column studies. International Journal of Environment and Waste Management, 4(4): 282-298.

Lee, G.F. and Jones-Lee, A. (1993). Groundwater pollution by municipal landfills. Leachate composition, detection and water quality significance. Proceeding of the 4th International Landfill Symposium, Sardinia, Italy, pp. 1093-1103.

Longe, E.O. and Enekwechi, L.O. (2007). Investigation on potential groundwater impacts and influence of local hydrogeology on natural attenuation of leachate at a municipal landfill. Int. J. Environ. Sci. Tech., 4(1): 133-140.

Longe, E.O. and Balogun, M.R. (2010). Groundwater Quality Assessment near a Municipal Landfill, Lagos, Nigeria. Res. Jour. of Applied Sci., Eng. and Technol., 2(1): 39-44.

Mohajeri, S., Aziz, M.H., Zahed, M.A. and Adlan, M.N. (2010). Statistical optimization of process parameters for landfill leachate treatment using electro-Fenton technique. J. Hazard Mat., 176(1-3): 749-758. 
NBS (2009). Federal Republic of Nigeria, National Bureau of Statistics. Archived from the original on 2009-03-25.

Ohwoghere-Asuma, O. and Aweto, K.E. (2013). Leachate Characterization and Assessment of Groundwater and Surface Water Qualities Near Municipal Solid Waste Dump Site in Effurun, Delta State, Nigeria. Journal of Environment and Earth Science, 3(9): 126-134.

Ojoawo, S.O., Agbede, O.A. and Sangodoyin, A.Y. (2012). Characterization of Dumpsite Leachate: Case Study of Ogbomosoland, South-Western Nigeria. Open Journal of Civil Engineering, 2(1): 33-41.

Pohland, F.G., Cross, W.H. and Gould, J.P. (1993). Metal speciation and mobility as influenced by landfill disposal practices. In: Metals in Groundwater (edited by Allen, H.E., Perdue, E.M. and Brown, D.S.). Lewis Publishers, Boca Raton, pp. 411-429.

Rafizul, I.M., Alamgir, M. and Islam, M.M. (2011). Evaluation of Contamination Potential of Sanitary Landfill Lysimeter Using Leachate Pollution Index. Proceedings of thirteenth International Waste

Management and Landfill

Symposium, Sardinia, Cagliari, Italy; 3 - 7 October 2011 CISA, Environmental Sanitary Engineering Centre, Italy.

SON (2007). Nigerian Standard for Drinking Water Quality. Nigerian Industrial Standard NIS 554, Standard Organization of Nigeria, pp: 30.

Tsarpali, V., Kamilari, M. and Dailianis, S. (2012). Seasonal alterations of landfill leachate composition and toxic potency in semi-arid regions. J. Hazard Mat. 233(234): 163-171.

WHO (2011). Guidelines for DinkingWater Quality. $4^{\text {th }}$ ed. Geneva, Switzerland, pp 541.

Yanful, E.K., Quigley, R.M. and Nesbitt, H.W. (1988). Heavy metal migration at a landfill site, Sarnia, Ontario, Canada - 2: metal partitioning and geotechnical implications. Applied Geochemistry, 3: 623-629.

Yoshida, M., Ahmed, S., Nebil, S. and Ahmed, G. (2002). Characterization of leachate from Henchir $\mathrm{El}$ Yahoudia close landfill. Water, Waste and Environment Research, 1(2): 129-142 